\title{
NOTES ON THE BIOLOGY OF \\ TWO CENTRAL AMERICAN PTINUS (COLEOPTERA: PTINIDAE) \\ WITH A DESCRIPTION OF A NEW SPECIES
}

\section{By Robin M. Andrews ${ }^{1}$}

In this paper, a new species of Ptinus and the larva of Ptinus latefasciatus Gorham are described from Costa Rica. The larval habitat was discovered and comments will be made on the biology of the two species. The only species life history that has been recorded for New World Ptinidae is that by Linsley and MacSwain (1942) on Ptinus californicus Pic, a depredator in the nests of solitary bees, and there are host records for only a few other native species. Most of our knowledge of the family comes from the work of Europeans who have been concerned mainly with economically important species. Field work was conducted during participation in the Insect Ecology course given by the Organization For Tropical Studies in Costa Rica during February and March, 1967. The study locality was at Finca Taboga, near Cañas, Guanacaste Province. Specimens have been deposited in the collection of the Museum of Comparative Zoology [MCZ].

I would like to thank Dr. J. F. Lawrence, Dr. D. H. Janzen and Mr. Robert Matthews for the critical reading of this manuscript. I am grateful to Mr. R. D. Pope of the British Museum [BM] for the loan of specimens of $P$. latefasciatus.

\section{Ptinus latefasciatus Gorham}

(Figs. I-I I, I 5, I6)

Ptinus latefasciatus Gorham, 1883: 194 (described from Vera Cruz, Mexico;

Cerro Zunil, Paso Antonio, Dueñas, Guatemala; David, Tole, Panama); Pic, 1900: 256; Papp, 1962: 411. Syntypes in the British Museum. Ptinus latefasciatus? var. tripartitus Pic, 1900: 256.

Ptinus mexicanus Pic, 1901: 299.

Description of adult: Sexual dimorphism absent. Patterned in black and reddish-brown; clothed with both black and gold setae;

\footnotetext{
${ }^{1}$ Museum of Comparative Zoology, Harvard University, Cambridge, Mass. Present address: Department of Entomology, University of Kansas, Lawrence, Kansas.

Published with the aid of a grant from the Museum of Comparative Zoology. Contribution No. 1370 from the Department of Entomology, The University of Kansas, Lawrence.

Manuscript received by the editor July 25, 1967
} 


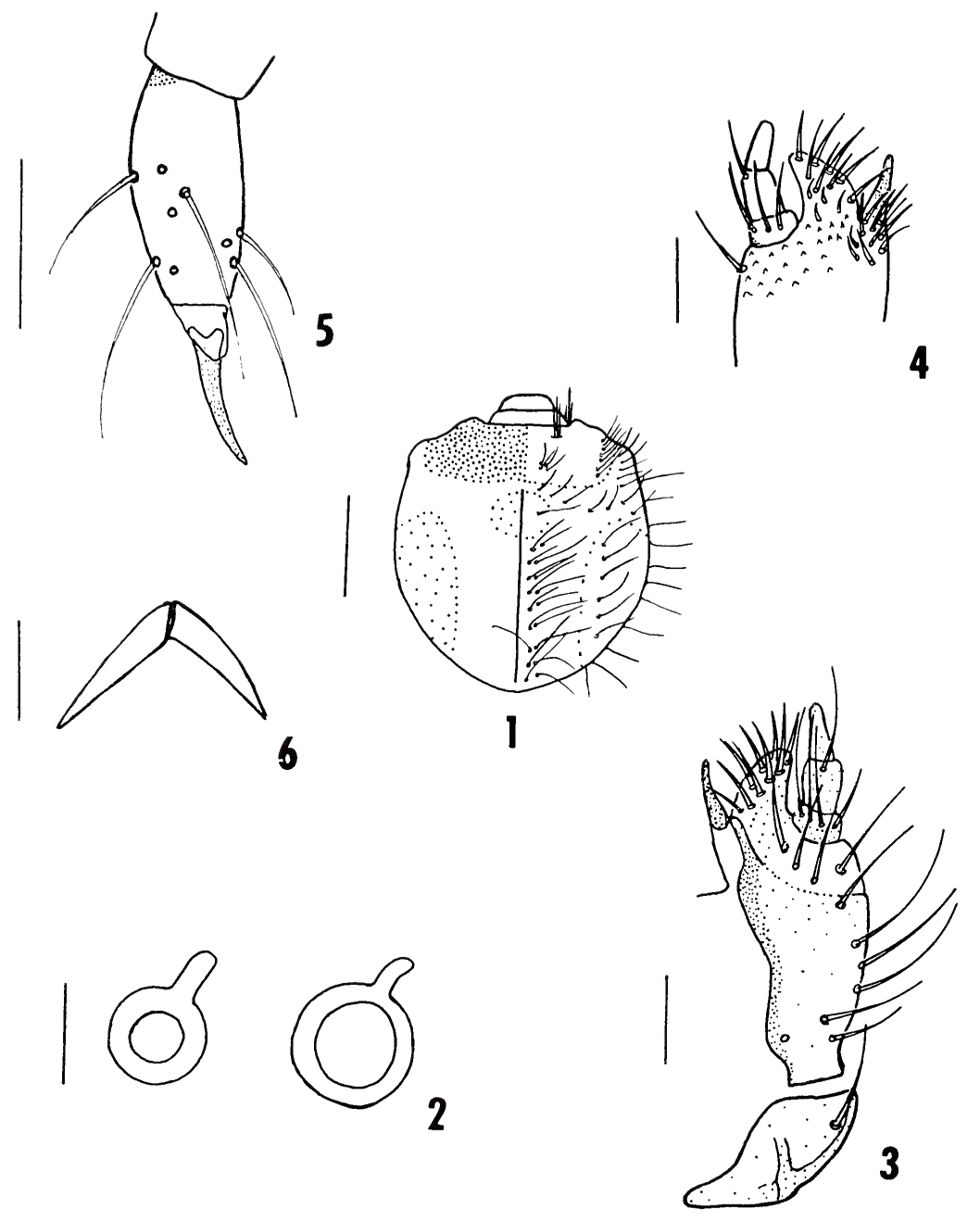

Larva of Ptinus latefasciatus Gorham

Fig. 1. Head capsule, dorsal view (scale $.34 \mathrm{~mm}$.). Fig. 2. Spiracles, right, thoracic spiracle, left, first abdominal (scale $.04 \mathrm{~mm}$ ). Fig. 3. Maxilla external view (scale $.1 \mathrm{~mm}$.). Fig. 4. Maxilla, internal view (scale .1 mm.). Fig. 5. Proleg, posterior view of left limb, setae of anterior side indicated by open circles (scale .1 mm.). Fig. 6. Preanal sclerite (scale $.13 \mathrm{~mm}$.). 
elytra with large preapical and prebasal streaks of white recumbent hairs. Total length: $2.64-3.50 \mathrm{~mm}$. Greatest width (across humeral callosities): I.IO-I.64 mm.

Redescribed from of collected at Finca Toboga, 6 mi. S., 6 mi. W. Cañas, Guanacaste Prov., Costa Rica, Feb. I7, 1967, sweeping, river-bottom forest. Total length: $2.7 \mathrm{I} \mathrm{mm}$. Greatest width (across humeral callosities): I.I $8 \mathrm{~mm}$. Head with shallow vertical impression between eyes, vertex finely granulate, dull black; sparse recumbent white hairs and stiffer, more erect black setae on front between eyes. Eyes moderately large, projecting beyond maximum width of prothorax, situated laterally, just above base of mandibles, diameter of each eye two-thirds distance between eyes, occasional setae between facets. Antennae extending to middle of elytra, stout, with fine pubescence and with sparse black setae as long as each segment, middle segments each about I.3 times as long as wide, basal segment twice as long as II, segments III-X slightly longer than II and subequal, ultimate segment $\mathrm{I} .9$ times as long as a middle segment. Pronotum with greatest width and length subequal, shiny black with basal half reddish-brown, anterior rim with long stiff black setae inclined posterad, anterior half coarsely granulate and strongly raised forming four gibbous areas, the central two not as distinctly separated from each other as they are from the lateral areas, clothed with stiff curved black setae that converge to a central point on each gibbosity, lateral and posterior sides of gibbosities with stiff golden setae, lateral gibbosities with a few white hairs preapically, posterior side of gibbosities with a median strip of short white hairs; lateral constrictions formed by deep vertical grooves that continue forward on each side between the lateral and central gibbosities as shallow, narrower grooves; basal half glabrous with a double row of setae at the basal edge, a deep median key-hole shaped groove extending to the raised area and slightly covered by a projection of this part. Scutellum U-shaped and covered with short white recumbent hairs. Wings fully developed. Elytra r.65 times as long as wide, sides parallel, humeral callosities strongly developed and raised, diameter of punctures at middle of elytra about one-third as great as interspace width; area between preapical and prebasal streaks black, sutural margin, apices of elytra and basal area reddish-brown, black setae confined to black areas of elytra which are elsewhere clothed with golden setae; inclined setae of strial punctures extending slightly beyond next puncture; erect setae of intervals moderately short, setae of odd intervals only slightly longer than setae of even inter- 
vals; preapical streak of recumbent white hairs extending from second interval to lateral edge of elytra, short posterior prolongations into interval four and along elytral edge, a broad diffuse band of white recumbent hairs between the humeri, prebasal streak extending from interval two to elytral margin, a short prolongation into interval six, an additional diffuse patch of white hairs between the prebasal streak and the apices of the elytra. Ventral surface uniformly clothed in yellowish-gold hairs. Abdomen with sternites one to three somewhat connate mesally, sternite two twice as long as four. Metacoxae transverse, separated by one-half their width. Legs black, stout, covered with rather long and stiff golden setae, femora sprinkled with short white hairs, setae on upper tibia stiff and bristly, finer and inclined distally, tarsi with segments I to IV gradually decreasing in length, $\mathrm{V}$ equal to II and III combined. Genitalia (Figs. 15, I6) like typical Ptinus with ventral basal piece and lateral lobes attached dorsally to the median lobe. Median lobe gradually enlarged, widest just before apex, lateral lobes embracing closely the median lobe, basal piece I.5 times as long as wide.

Description of mature laRvae: General body form as in other described ptinid larvae (Böving 1956, Manton 1945). Total length: 4-5 mm. Head (Fig. I) hypognathous, pale yellowish-white, epicranial sulcus extending to the anterior third; three dorsal sclerotized areas: anterior third dark brown, small central patch and lateral areas yellowish-tan. Setae fine, white; four parallel rows on each side extending about midway from the rear edge, the two rows near the epicranial sulcus approximate, a single pair of setae in the central sclerotized area. Dark anterior area with two series of short setae marginally, four shorter setae near the midline, anteriorly an elongate pit with three to four setae, a second such structure with three setae on the anterior edge of the head at the lateral border of the anticlypeus, both with long setae projecting forward over the labrum. Antennae consisting of a sclerotized ring in a membranous socket located in the anterior edge of the head slightly above and mesal to the dorsal mandibular articulation. Tactile appendix of the antennae cone shaped, twice as long as wide, surrounded by several smaller sensory setulae. Anticlypeus rectangular, membranous. Labrum (Fig. 8) twice as wide as long, gradually curved distally; long setae born on the anterior edge and on either side basally, Y-shaped sclerites or tormae extending through the anticlypeus into the labrum; three basal labral sensillae: one on the midline and one between the arms of each torma. Epipharynx (Fig. 9) with four to six short 

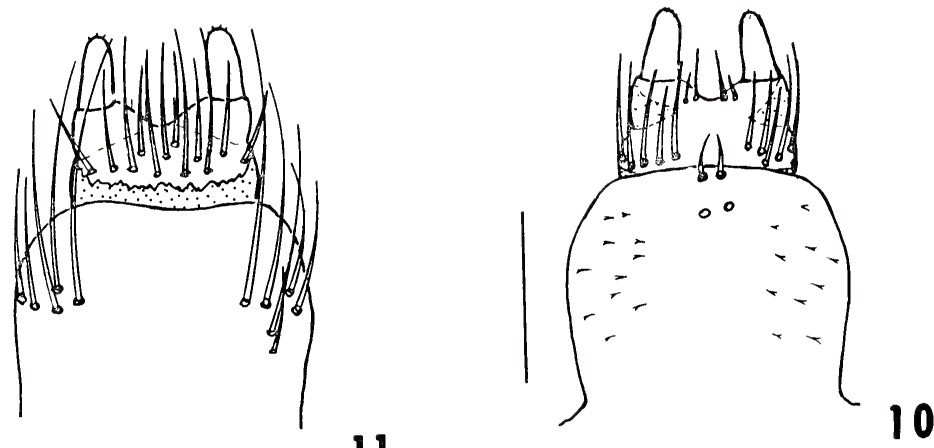

11
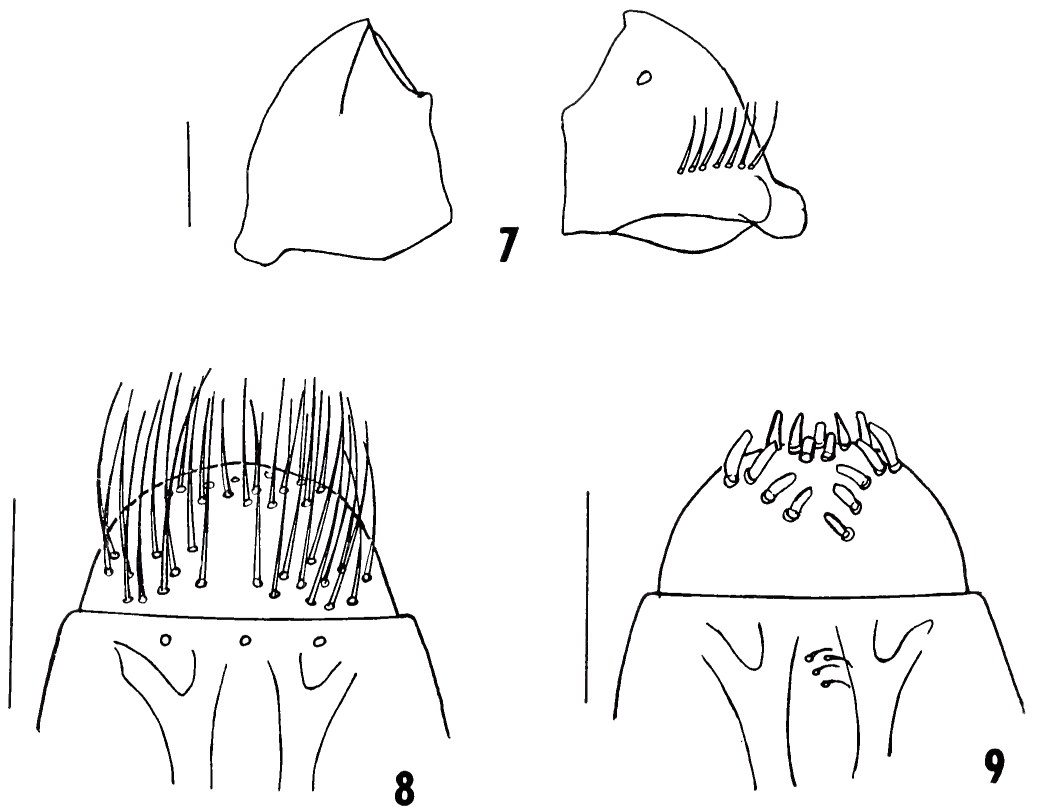

Larva of Ptinus latefasciatus Gorham

Fig. 7. Mandibles, right, external view, left, internal view (scale $.13 \mathrm{~mm}$.). Fig. 8. Labrum, external surface (scale .1 mm.). Fig. 9. Epipharynx (scale .1 mm.). Fig. 10. Labium, internal view (scale .1 mm.) Fig. 11. Labium, external view (scale .1 mm). 
blunt setae in each diverging row, similarly shaped setae on the anterior edge, and three or four short curved setae between the tormae. Mandibles (Fig. 7) slightly longer than greatest width, heavily sclerotized, dark brownish-black, with a single apical tooth; outer surface convex, with slight irregularities basally, a row of stiff setae paralleling the base, a somewhat elongate, mesal, preapical pit; inner surface convex, with a concave area mesally between apex and small acute tooth on the inner margin; inner margin compressed distal to the small tooth and more rounded proximal to it. Maxilla (Figs. 3, 4): cardo somewhat rhomboid, with one long setae on external distal surface; stipes two times as long as broad, with long setae on external lateral surface; palpus with three segments, the first short and broad, circled apically by about eight long setae, the second almost twice as long as the first, with two apical setae, the third subequal to the second, narrowed distally, apex with tiny sensory setulae; galea extending just beyond apex of second segment of the palpus, with numerous stout curved setae proximally; lacinia consisting of a well sclerotized spine, a number of short setae basally on the internal side. Labium (Figs. IO, II): mentum large and fleshy, prementum smaller, about two-thirds width of the mentum; on the internal surface, mentum bearing numerous spicules laterally, two short stiff setae anteriorly and mesally, prementum with nive or six setae on either side, two pairs of short setae projecting between the palps; on the external surface, the mentum with a group of about six long setae on either side, the prementum bordered basally by a sclerotized band, with numerous long setae anteriorly; labial palpus with two segments, the basal low and membranous with a small triangular sclerotized area on the internal surface, ultimate article longer than the first, apex with tiny sensory setulae. Preanal sclerite (Fig. 6) small, $\mathrm{V}$ or U-shaped, with arms asymetrically developed, enclosing only the very anterior end of the anal cushion. Spiracles (Fig. 2) annular with a single spout, thoracic spiracles I.5

EXPLANATION OF PLATE 29

Ptinus costaricensis n. sp.

Fig. 12. Pronotum, dorsal view, stippling of surface structure and not indicating setation (scale $.31 \mathrm{~mm}$.). Fig. 13. Genitalia, holotype $\hat{o}$, dorsal view, basal piece removed, setae indicated only for right lateral lobe (scale .13 mm.). Fig. 14. Genitalia, holotype $\hat{o}$, ventral view (scale .13 mm.).

Ptinus latefasciatus Gorham

Fig. 15. Male genitalia, dorsal view, basal piece removed, setae indicated only for right lateral lobe (scale $.13 \mathrm{~mm}$.). Fig. 16. Male genitalia, ventral view (scale $.13 \mathrm{~mm}$.). 

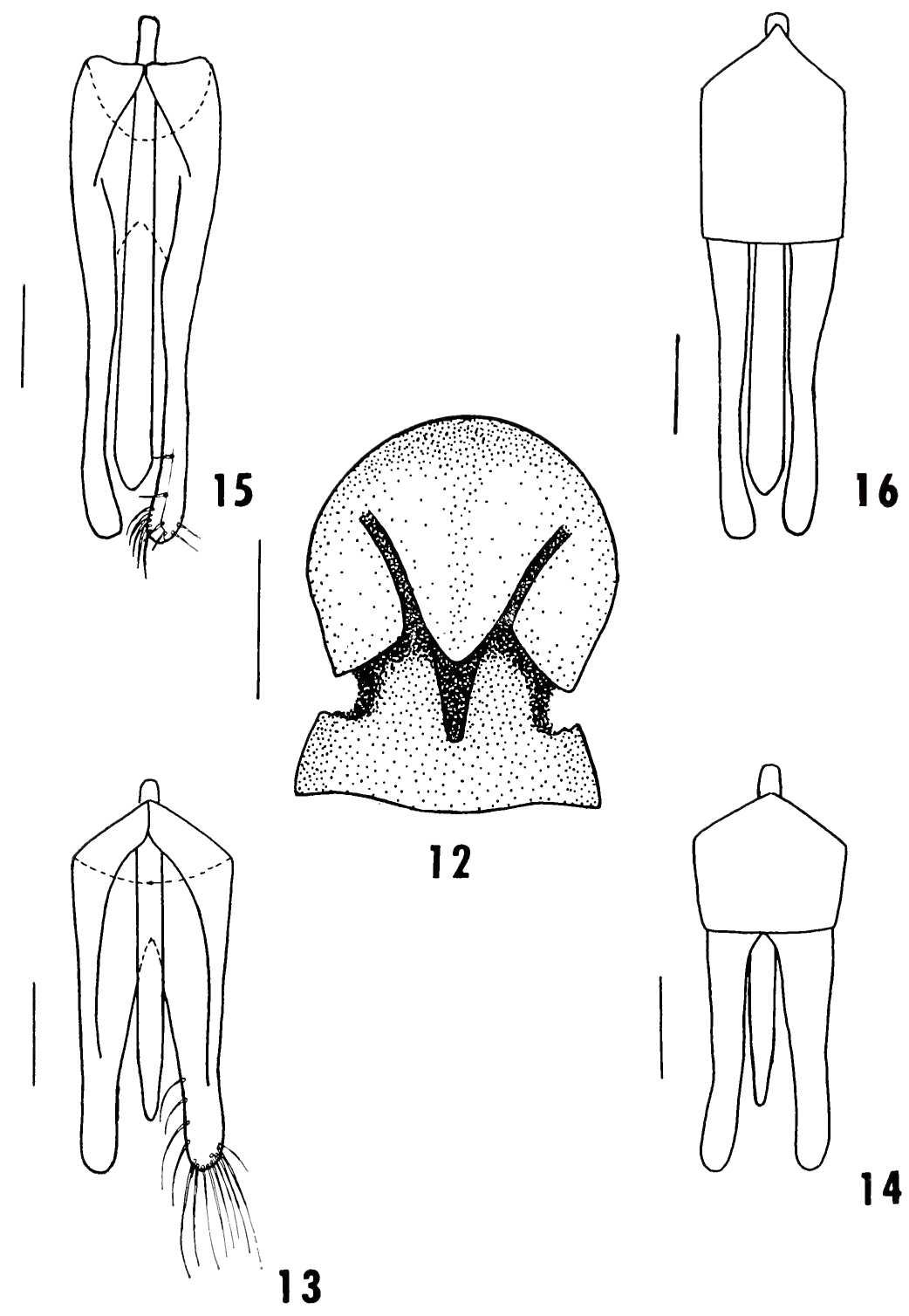

Andrews - Ptinus 
times as wide as the abdominal spiracles and with a less prominent spout. Legs (Fig. 5): proximal one-third of tibio-tarsus without setae, distal two-thirds with six to ten setae; pretarsus without setae, consisting of a soft basal portion and a long tapering claw, empodial lobe extending to basal fourth of the claw.

The nature and degree of variation is similar to that noted by Manton (1945) and Hall and Howe (1953), primarily differences in the numbers of setae and asymetry of certain parts. This variation was particularly noticeable in the mouthparts. Although the numbers of setae within groups or clusters vary between individuals, and from side to side on the same specimen, the placement of these groups appears to be invariable and probably is species' specific.

Although adults of two species were reared from the scats, the larvae are believed to be those of Ptinus latefasciatus because (I) this was the most numerous adult reared, eleven of this species to three of $P$. costaricensis, (2) pupae collected are $P$. latefasciatus by total length measurements $(2.8-3.2 \mathrm{~mm}$.) and (3) of the large size of the mature larva.

The larva of Ptinus latefasciatus can be distinguished from its North American congener, P. californicus (Böving, 1956), by numerous characters, some of which are listed in the following table.

\section{Ptinus californicus}

cardo with three setae epipharynx with I-3 setae in diverging rows spiracle without spout tibia with I6 setae pretarsus with setae

\section{Ptinus latefasciatus}

cardo with one setae epipharynx with $4-6$ setae in diverging rows spiracle with spout tibia with less than io setae pretarsus without setae

By the last mentioned character $P$. latefasciatus can be distinguished from $P$. californicus and all the species in Hall and Howe's larval key. Distribution: Central America (Mexico, Guatemala, Costa Rica and Panama) and South America (Colombia, British Guiana and Brazil).

Material examined: Costa rica: Guanacaste Prov., Taboga, 6 mi. S., 6 mi. W. Cañas, I0 ${ }^{\circ}$ I $^{\prime}$ N., $85^{\circ}$ og' W., Feb. I 5, I967, collected from coati scats, 6 larvae. Same locality, Feb. I7, I967, reared from coati scats, I I adults. Same locality, Feb. I7, I967. sweeping river-bottom forest, 4 adults. colombia: Rio Frio, Mgd., 2 specimens; Sta. Marta, Mgd., I specimen; Aracataca, Mgd., 5 specimens; Sevilla, Mgd., I specimen; Darlington collector [MCZ]. 
BRITISH GUIANA: Rio Essequibo (source), J. Ogilvie collector [MCZ]. guatemala: Dueñas, G. C. Champion, B.C.A. Coll. III. (2)., Syn-type [BM].

Ptinus costaricensis, new species

(Figs. I 2-I 4)

Holotype.- $\sigma^{x}, \operatorname{costa}$ RICA: Guanacaste Prov., Taboga, 6 mi. S., $6 \mathrm{mi}$. W. Cañas, $10^{\circ} 19^{\prime}$ N., $85^{\circ}$ og $^{\prime}$ W., Feb. I7, 1967, reared from coati scats [MCZ, No. 3155I]. Allotype, $\odot$, same date and locality, sweeping, river-bottom forest [MCZ].

Paratypes.-2, same data as holotype [MCZ: I]; 4, same locality as holotype, Feb. I5, 1967, sweeping, river-bottom forest [MCZ: I].

Description: Sexual dimorphism absent. Reddish-brown, head and prothorax black with black extending into the anterior half of the elytra along the midline; clothed with gold setae; elytra with small preapical and prebasal streaks of white recumbent hairs. Total length: 1.90-2.65 mm. Greatest width (across humeral callosities) : .78 - $1.15 \mathrm{~mm}$.

Holotype $0^{7}:$ Total length: $2.65 \mathrm{~mm}$. Greatest width (across humeral callosities): $1.13 \mathrm{~mm}$. Head, eyes and antennae as in P. latefasciatus. Pronotum (Fig. I2) shiny black, I.2 times as long as wide, grooves and setation as in P. latefasciatus but without short white hairs on gibbosities. Scutellum and wings as in P. latefasciatus. Elytra I.7 times as long as wide, sides parallel, humeral callosities strongly developed and raised; diameter of strial punctures at middle of elytra about 0.5 times as great as interspace width; inclined setae of strial punctures extending to next puncture, erect setae of interspaces longer than in P. latefasciatus, those of odd intervals I.5 to 2 times longer than those of even intervals; recumbent white hairs of preapical streak extending from fourth to eighth interval, prebasal streak extending from the second to the fourth interval, and slightly posteriorly, from the fifth to the eighth interval. Metasternum clothed with intermingled gold and white hairs extending into the lateral areas of the metasternum. Abdomen and metacoxae as in P. latefasciatus. Legs reddish-brown, otherwise as in P. latefasciatus. Genitalia (Figs. 13, I4) relatively shorter than in $P$. latefasciatus, medium lobe narrowed at the apex, lateral lobes rounded apically, not closely approaching medium lobe, basal piece with length and width subequal.

This species is extremely similar to P. latefasciatus in proportions and in the structure of the pronotum. P. costaricensis is the smaller 
and more slender of the two species; there is little overlap of the gross measurements and the elytra and pronotum are relatively longer than in $P$. latefasciatus. Connation of the abdominal sternites is stronger in $P$. costaricensis. Superficially, $P$. costaricensis can be distinguished by it slighter coloration and smaller streaks of recumbent white hairs. The pronotal structure of these species is unique for New World Ptinus and separates these species from the $P$. interruptus group of Fall (I905), the species of which are patterned similarly to $P$. latefasciatus.

\section{Biology}

Ptinus costaricensis and P. latefasciatus were found to be breeding in coati (Nasua narica) scats. Coati troops were observed to use logs and large branches on the ground as part of their travel routes through the river-bottom forest along the Rio Higueron. Their feces, small flat cakes 5-6 cm. or less in diameter, were very numerous on these exposed surfaces. Many of the dry scats contained one to several larvae and pupae, and adults subsequently emerged from collected material. Naked pupae were in cavities in the scats; the larvae do not construct cocoons as has been noted for other ptinid species (Howe and Burgess, I952).

Small dry deposits of fecal material may be the natural reservoir for many ptinid species as indicated by the few records for native species and some economic pests. Hinton (I94I) summarizes the host data for British species, including nearly all of the economically important Ptinidae. The latter are known from a diverse assortment of dried organic materials, from stored cereals and grains to soiled clothing, bath sponges and opium cakes. Species that have successfully invaded the stored products habitat probably have come from several natural habitats, one of these being animal feces. For example, Niptus hololeucus Fald., a cosmopolitan pest in stored products, has been collected from rodent droppings (Hinton, 194I). Reddell ( I966) has collected a new species of Niptus from raccoon scats in a Texas cave and several other species have been described by Brown (1959), also from caves and these may have similar habits. Ptinids recorded from bird nests (Linsley 1944, Woodroffe 1953) may also be associated with fecal material.

Adults of $P$. latefasciatus and $P$. costaricensis were commonly collected by sweeping understory vegetation of the river-bottom forest but were not taken in drier sites away from the river. As native ptinid species are rarely encountered by collectors, the occurrence of 

Hinton, H. E.

1941. The Ptinidae of economic importance. Bull. Ent. Res., 31: 331381.

HOLDRIDGE, L. R.

1964. Life Zone Ecology. Tropical Science Center, San Jose, Costa Rica. 124 pp.

Howe, R. W. ANd H. D. Burgess.

1952. Studies on beetles of the family Ptinidae, VII, Biology of five ptinid species found in stored products. Bull. Ent. Res., 43: 153186.

Linsley, E. G.

1944. Natural sources, habitats, and reservoirs of insects associated with stored food products. Hildgardia, 16: 187-224.

Linsley, E. G. and J. W. MacSwain.

1942. The bionomics of Ptinus californicus, a depredator in the nests of bees. South. Calif. Acad. Sci. Bull., 40: 126-137.

Manton, S. M.

1945. The larvae of the Ptinidae associated with stored products. Bull. Ent. Res., 35 : 341-366.

PAPP, C. S.

1962. Catalogue of the Ptinidae of North America. Deutsche Ent. Z., $9: 367-432$.

PIC, M.

1900. Contribution a l'etude des Ptinidae de L'Amerique Centrale et Meridionale. Ann. Soc. Ent. Belg., 44: 251-258.

1901. Un nouveau Ptinus du Mexique (Col.). Bull. Soc. Ent. Fr., p. 299. REDELL, J.

1966. A checklist of the cave fauna of Texas. II. Insecta. Texas J. Sci., 18: 25-56.

Woodroffe, G. E.

1953. Ecological study of the insects and mites in nests of certain birds in Britain. Bull. Ent. Res., 44: 739-772. 


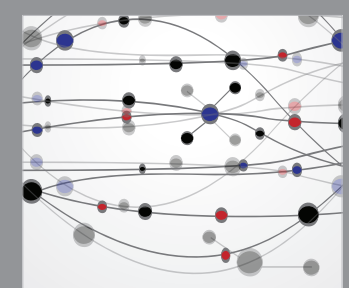

The Scientific World Journal
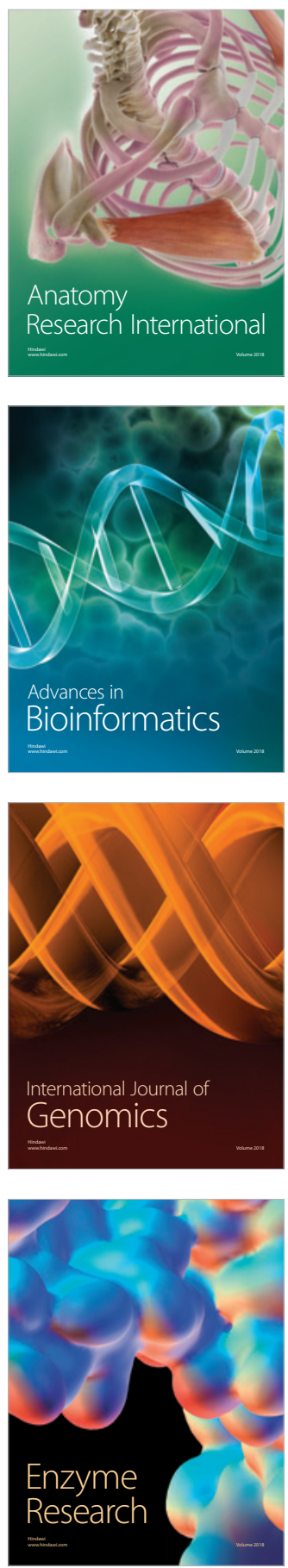
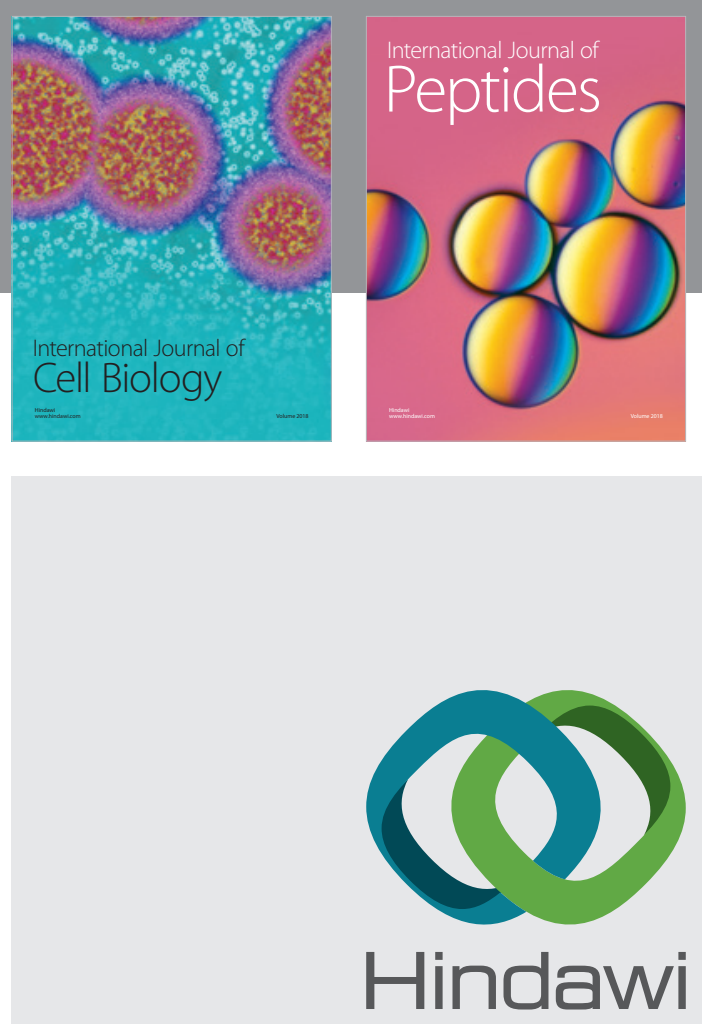

Submit your manuscripts at

www.hindawi.com
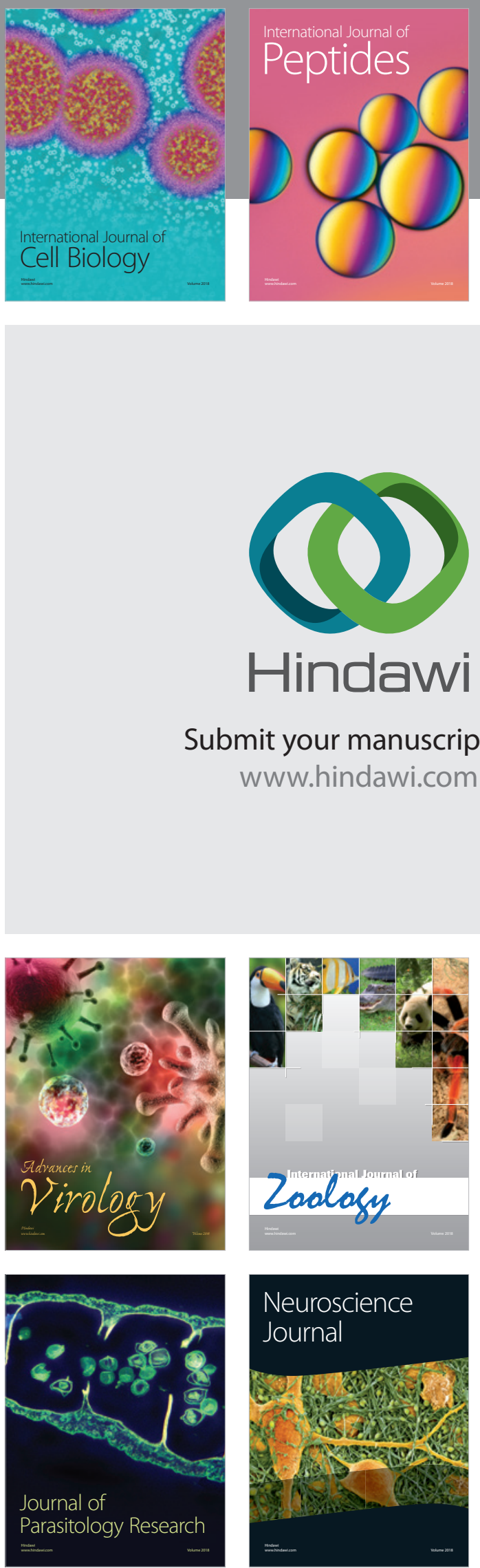
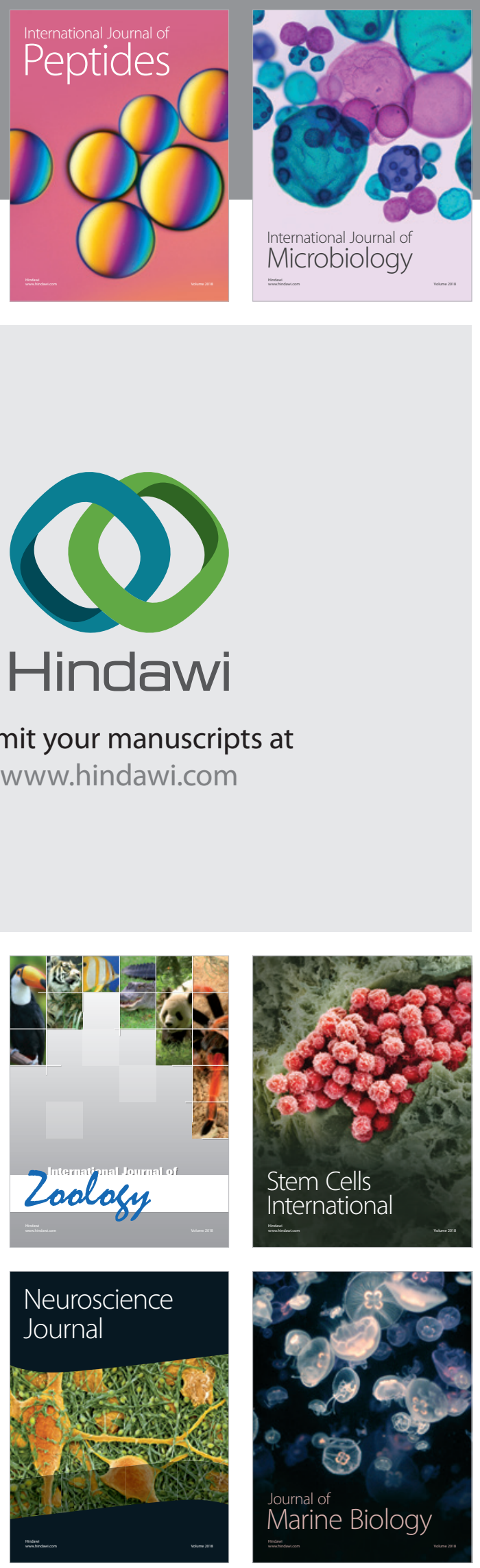
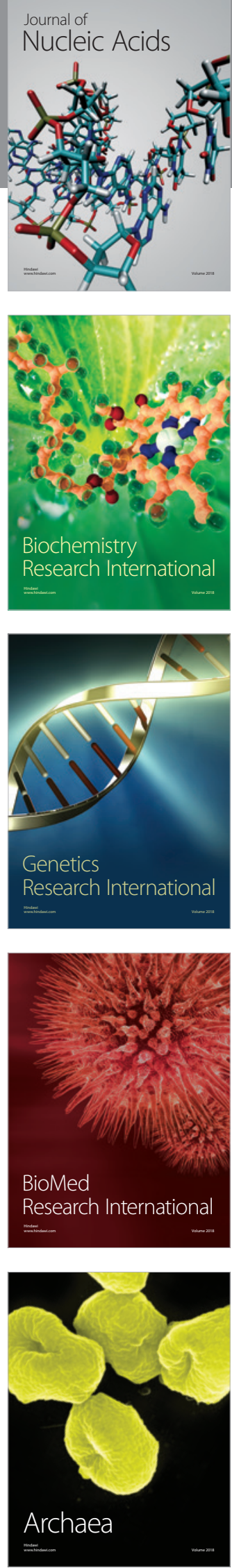